\title{
Particularities in the Surgical Technique of Calvaria Graft
}

\author{
Particularidades en la Técnica Quirúrgica de Injerto de Calota \\ Ramalho Gabriel Ferreira*; Leonardo Perez Faverani*; Ellen Cristina Gaetti Jardim; Ana Cláudia Rossi"; \\ Tárik Ocon Braga Polo*; Osvaldo Magro Filho*; Roberta Okamoto* \& Idelmo Rangel Garcia Júnior*
}

FERREIRA, G. R.; FAVERANI, L. P.; JARDIM, E. C.; ROSSI, A. C.; POLO, T. O. B.; FILHO, O. M.; OKAMOTO, R. \& JÚNIOR, I. R. G. Particularities in the surgical technique of calvaria graft. Int. J. Odontostomat., 6(3):317-322, 2012.

ABSTRACT: Calvaria grafts provide good bone quantity for the reconstruction of the atrophic maxilla, and have lower morbidity and resorption rates when compared to iliac crest. The aim of this paper is to present the technique for obtaining a graft of the skull. Initially, the depth of the osteotomy is determined by a manually conducted bur, which establishes the limits of the structures of the skull (outer table, diploe and inner table), making the removal of bone blocks easier and safer. Thus, osteotomies of the blocks are made with greater security, avoiding the complications inherent to surgical technique. The case that will be presented it is from a male patient of 65 years who refused to submit to the iliac crest graft, opting for the calvaria, despite being bald, that is a contraindication for this treatment modality. A delicate suture associated with placement of titanium mesh to maintain the conformation of the patient's skull in the region of the bone defect, created after removal of the graft, provided a good cosmetic result at the donor site. The use of titanium mesh for re-anatomization of bone defects created in the grafts is well indicated for bald patients.

KEY WORDS: skull, jaw, atrophy, osteotomy.

\section{INTRODUCTION}

The increase in life expectancy associated with the advancement of science and technology have led to patients who need dental treatment involving advancedsurgical and prosthetics procedures. In this context, partially or completely edentulous patients that are physically able to undergone bone grafts and dental implants are restored by fixed prosthesis, recovering your chewing function, facial esthetics, smile, and especially their self-esteem, that improves life quality and reintegrate them into society (Iturriaga \& Ruiz, 2004).

However, the maxilla resorption process due to teeth loss makes the oral rehabilitation difficult, requiring prior bone grafting to restore bone in height and / or thickness, allowing subsequent installation of osseointegrated implants (Iturriaga \& Ruiz; Nyström et al., 2004).

In this context, the autogenous bone grafts are considered the "gold standard" because its osteogenic, osteoinductive and osteoconductive properties (Orsini et al., 2003; Prolo, 1987), which makes them the first choice for professionals. Thus, in the large reconstructions of maxillary atrophy, extraoral areas, mainly arising from the iliac crest or skull, are well set (Ramalho-Ferreira et al., 2010; Sbordone et al., 2009; Sjöstrõm et al., 2007).

The calvarial graft presents less morbidity and lower resorption rates in the long term, but has the disadvantage of a visible scar in bald patients (Prolo; Ramalho-Ferreira et al.; Sbordone et al.).

Therefore, the proposal to introduce the technique for obtaining a graft from the skull, precisely performed to minimize the transoperative complications, by means of a case report, justifies this work. In addition, we will present a technical innovation, the installation of a titanium mesh in the donor region to correct the defect created in a patient bald.

\footnotetext{
* Department of Surgery and Integrated Clinics, Faculty of Dentistry of Araçatuba, Paulista State University (UNESP), Araçatuba, SP, Brazil. " Department of Morphology, Anatomy area, Piracicaba Dental School, State University of Campinas - UNICAMP, Sao Paulo, Brazil.
} 


\section{CASE REPORT}

A Caucasian male patient, 65 years old, with maxillary arch totally edentulous about 30 years, complaining of its instable denture, sought assistance for the rehabilitation with dental implants. On physical examination, patient was in good general condition, walking, hydrated, eupneic, denied any underlying diseases, blood dyscrasias or drug allergies. On extraoral examination was seen a decrease in the lower third of the face and accentuated nasolabial folds, mimicking a horizontal and vertical deficiency of the maxilla (Fig. 1).

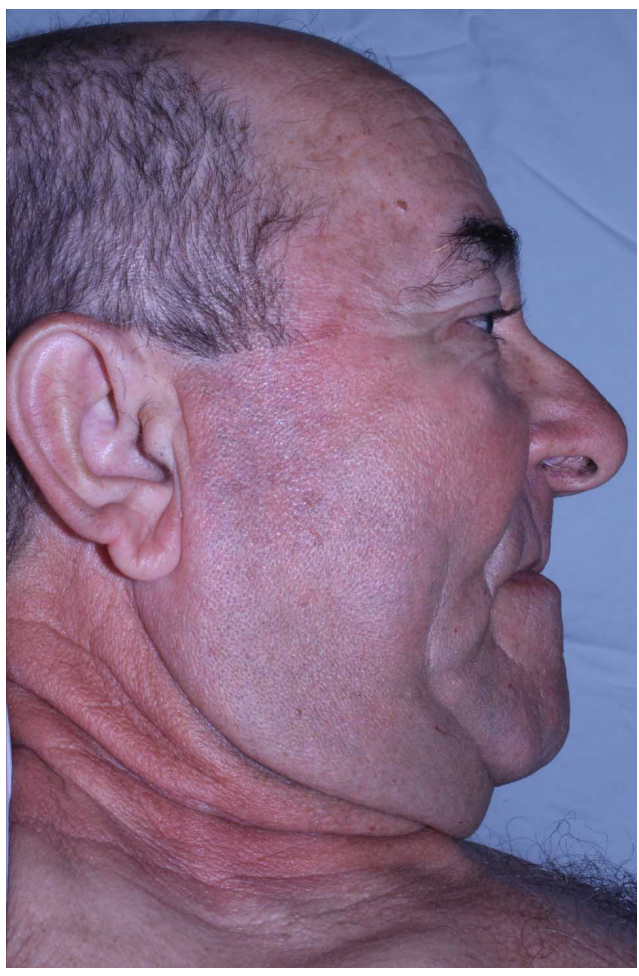

Fig. 1. Clinical patient's preoperative aspect with decreased lower third of the face and accentuated nasolabial folds mimicking anteroposterior and vertical maxillary deficiency.

On intraoral examination, severe maxillary atrophy was demonstrated in radiographic examination, in which there was an alveolar extension of maxillary sinuses. The lower teeth were in good periodontal health.

It has been proposed the reconstruction of the maxilla with autogenous bone graft from an extraoral donor area, due to the need of a large amount of bone. The interesting point of this case is that after the clarification of the advantages and disadvantages of donor sites with respect to morbidity, the patient refused to undergo the access to the iliac crest, preferring the graft from the skull. Even after has been explained that because he is bald there was a possibility of a cosmetically unfavorable scar.

Thus, under general anesthesia by nasotracheal intubation, the patient underwent the surgical procedure for maxilla reconstruction using calvarial bone graft. Initially it was performed antisepsia and subperiosteal anesthesia with vasoconstrictor (lidocaine 2\% Adrenaline 1: 100,000 - Xylestesin ${ }^{\circledR}$, Brazil) by a neurosurgeon, to facilitate the exposure of the donor area and achieve a bloodless surgical field (Fig. 2). The incision was made parallel to the sagittal suture, avoiding damage to the sagittal sinus, and directed toward the orbital apophysis, involving all layers of the scalp, from the skin to pericranium to access the posteromedial portion of the parietal bone on the right side. In this region there is a greater thickness of the skull, as well as the left side of the brain responsible for speech and motor skills on the right side of the body is avoided (Fig. 3).

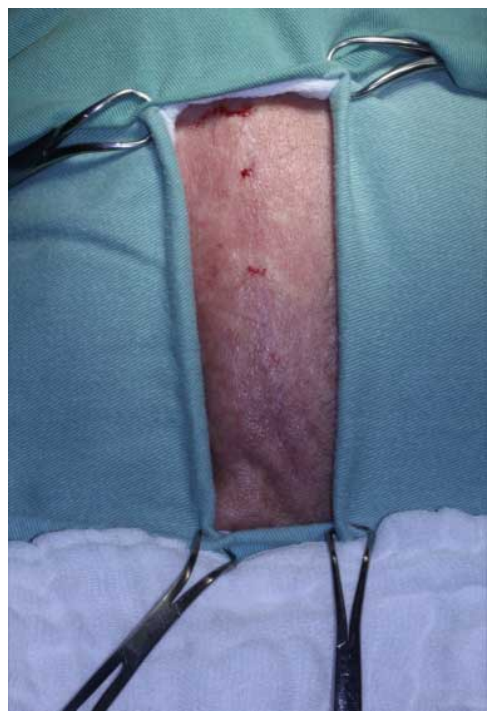

Fig. 2. Appearance of the surgical field after subperiosteal infiltration anesthesia to facilitate access and provide hemostasis.

Then the clips were placed for hemostasis, and as a modification of conventional technique for removing the calvaria graft, a manual trephine was used to locate the diploe relative to the inner 
cortex of the skull (Fig. 4). The neurosurgeon did the trephination trough outer table, diploe, and when the boundary between the diploe and inner table was reached, the depth of the osteotomy was defined (Fig. 5). The same procedure was performed on the other end of the wound, and after that drills under copious irrigation with saline solution were used for the demarcation of the bone blocks with about $10 \mathrm{~mm}$ each (Fig. 6).

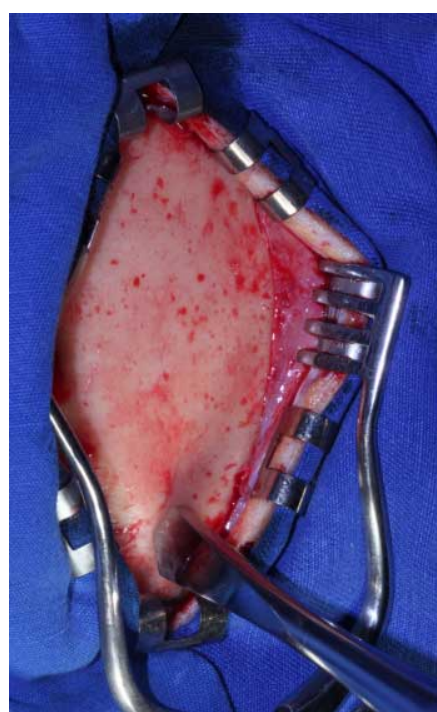

Fig. 4. Use of a manually conducted bur to determine the depth of the osteotomy.

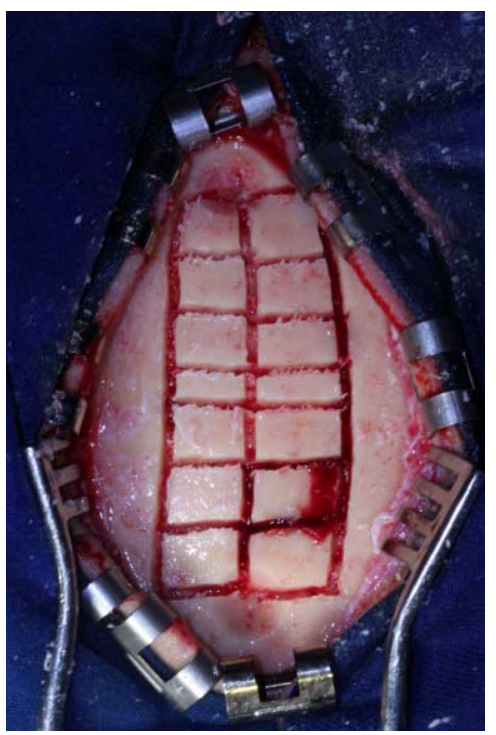

Fig. 6. Blocks already defined for removal with chisel and hammer.

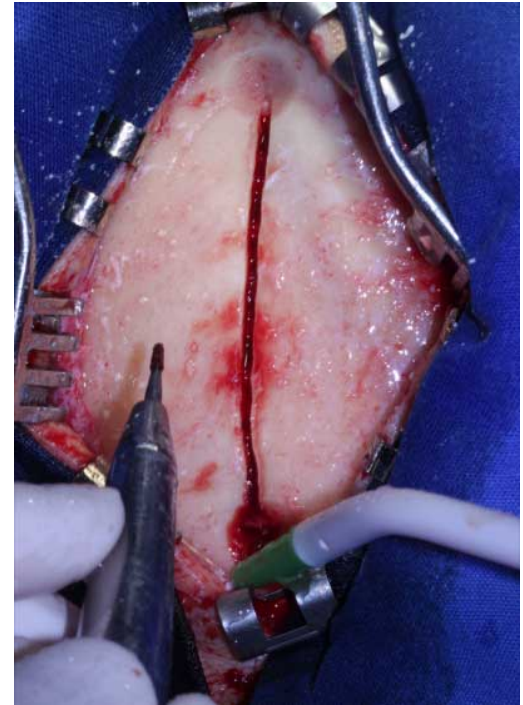

Fig. 5. Delimitation, made with surgical drill, of the area where will be removed the bone blocks.

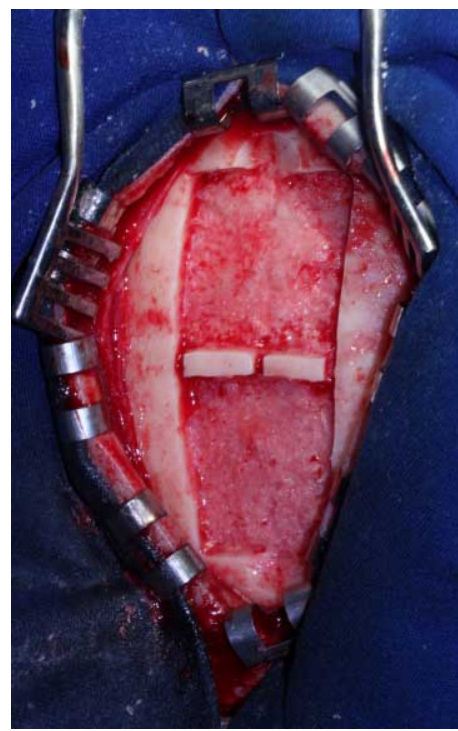

Fig. 7. Clinical aspect of the defect after the application of bone wax for homeostasis.

The blocks were carefully removed with chisel and hammer, leaving a bridge of bone tissue in the center of the defect to support the titanium mesh, avoiding thisway an aesthetically unpleasant depression at the site, in the bald patient. After hemostasis with bone wax (Bone Wax W-31, Ethicon) (Fig. 7), a titanium mesh $(1.5 \mathrm{~mm}$ system) was fixed with screws of the same system (Fig. 8). The suture was performed with 3-0 Polyglactin 910 (Johnson \& Johnson Company, São José dos Campos, Brazil) on the inner planes and 4-0 Nylon (Johnson \& Johnson Company, São José dos Campos, Brazil) on the skin.

So the surgery went ahead with total exposition of maxilla by the Oral and Maxillofacial Surgery staff, the maxillary sinuses was bilaterally elevated, the blocks were fixed with titanium screws to gain ridge thickness, and finally the maxillary sinuses were filled with bone particles (Fig. 9).

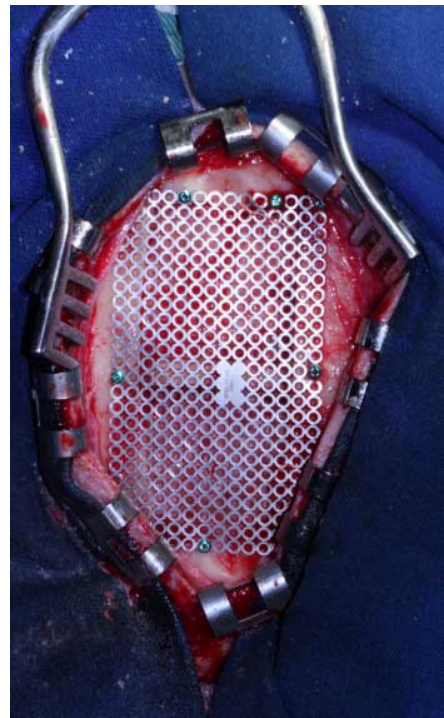

Fig. 8. Installation of a titanium mesh for the conformation of the skull in the bald patient.

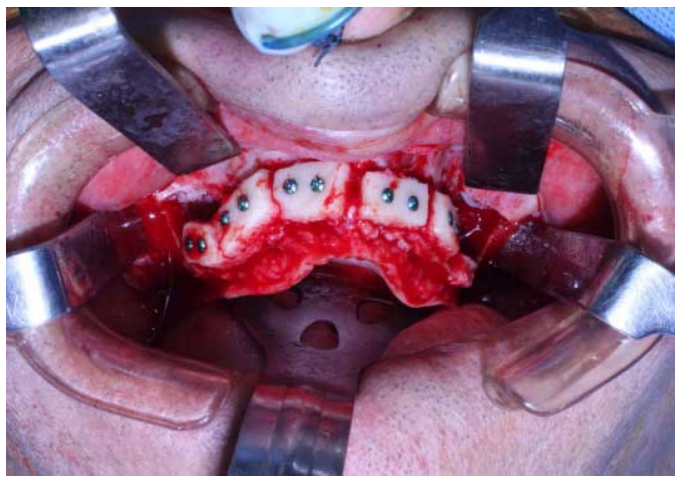

Fig. 9. Maxilla aspect after the bilateral maxillary sinus elevation and installation of bone blocks fixed with titanium screws. 


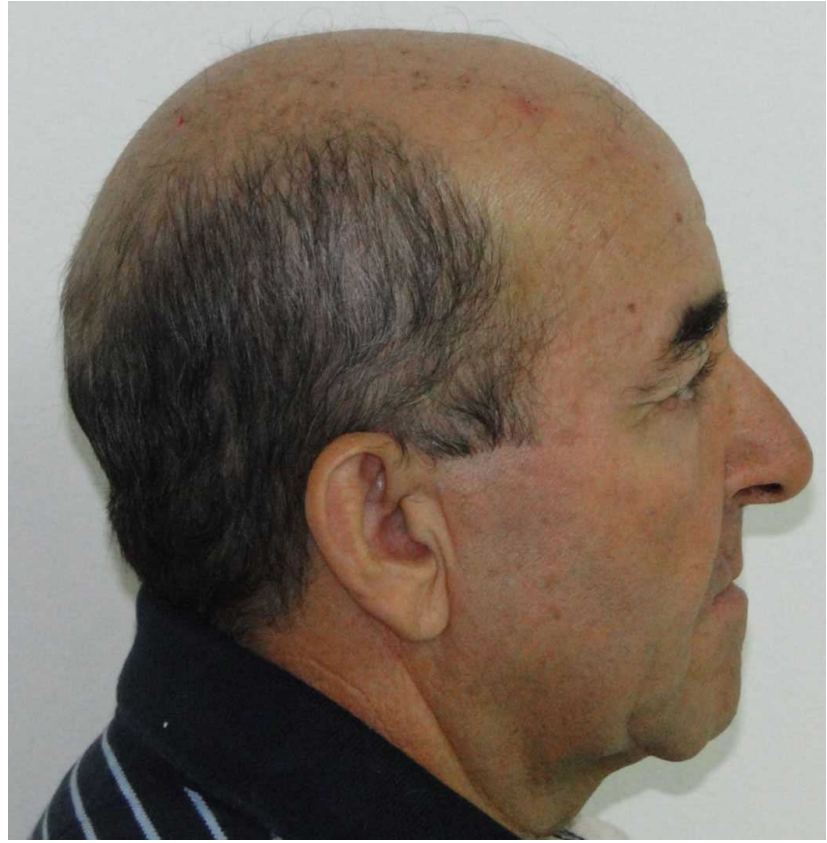

Fig. 10. In the postoperative period of 30 days, a good healing aspect of the surgical approach was shown.
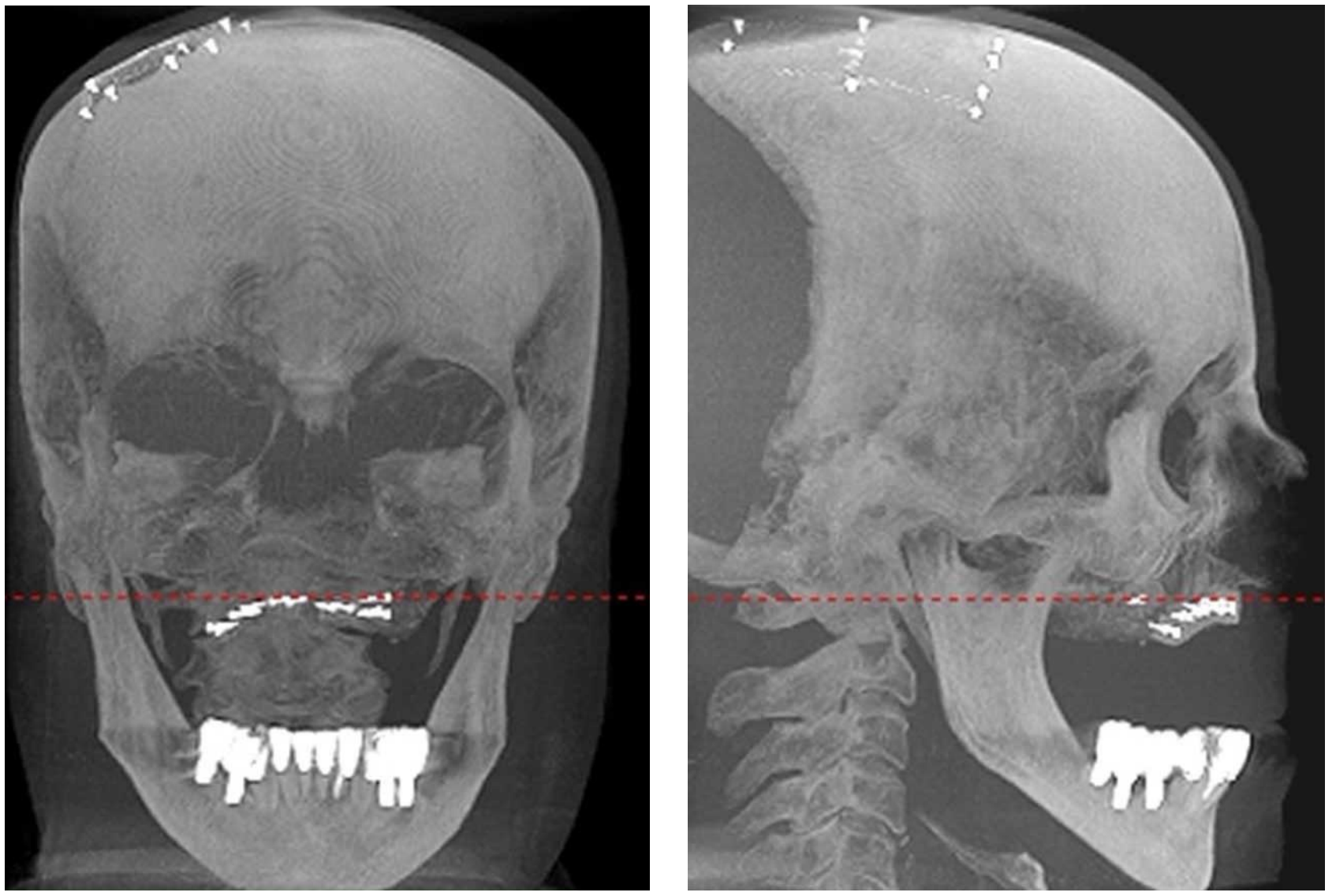

In follow-ups after the surgery, it was noted good healing aspect, both in the donor (Fig. 10), and receptor site. The patient denied history of keloids in the preoperative evaluation, and we found a good healing of the scalp postoperatively. So despite being a bald patient, when a careful suture of the wound is performed in a patient with a history of good healing, a satisfactory result can be obtained with this access. In the postoperative $\mathrm{CT}$, was noted the stability of titanium mesh installed in the donor area (Fig. 11).

\section{DISCUSSION}

The quest for beauty, for an aesthetic and harmonious smile, makes individuals increasingly seek out the dentist for the restoration of occlusal function and esthetics (Faverani et al., 2010; Frodel et al., 1993; Iturriaga \& Ruiz; Nyström et al.; Orsini et al.; Prolo; Ramalho-Ferreira et al.). Coupled to this, with increasing life expectancy of the population, there was

Fig. 11. Computed tomography postoperatively. 
an increase in the number of elderly patients seeking oral rehabilitation. Previously, the dentures and removable or partial fixed dentures were the only options for the restoration of edentulism. With the discovery of osseointegration, the implant-supported prostheses have revolutionized the oral rehabilitation (Albrektsoon et al., 1981). Patients are able to enjoy a very successful prediction of close to $100 \%$, improving the quality of their lives.

In this context, as in this study, the physiological process of bone resorption due to prolonged use of dentures, over time lead to the atrophy of maxilla, which contra-indicate the installation of dental implants without first undergoing reconstruction with bone grafts, to gain both height and thickness. The patient's upper teeth had been extracted for nearly 30 years, a common situation in most of senile Brazilian population, and consequently there was a severe atrophy of the maxilla.

In most of these cases the degree of resorption is very significant, for that reason, grafts from oral cavity removed under local anesthesia become limited (Schwartz-Arad \& Levin, 2007; Sbordone et al.). Thus, regions such as the iliac crest, calvaria, tibia, fibula, rib, are preferred in these cases (Iturriaga \& Ruiz; Nyström et al.; Orsini et al.; Prolo). The iliac crest and skull are frequently chosen as donor sites for this kind of treatment (Sbordone et al.; Sjöstrom et al.; Strong \& Moulthrop, 2000). It is known that the calvaria graft has lower morbidity when compared to iliac crest, both by the reduced postoperative pain and for not cause difficulty in walking (Iturriaga \& Ruiz; Nyström et al.; Orsini et al.; Prolo; Sbordone et al.).

However, in patients with hair loss there is the inconvenience of aesthetically unfavorable scarring, as well as many patients does not deal well psychologically with the fact that a portion of the skull will be removed (Iturriaga \& Ruiz; Prolo; Sbordone et al.).

Even with the clarification of the inconveniences of the calvarial graft in the bald individuals, the patient of this report did not wanted the iliac crest as the donor site, opting for the calvaria. What makes this case very interesting, since the surgical approach was performed respecting the principles of synthesis, which promoted an aesthetically satisfactory scar result. In addition, an important procedure was the installation of the titanium mesh to maintain the conformation of the skull, since the patient was bald.

Regarding the surgical technique for removal of the bone blocks of the skull, neurosurgeons promotes a osteotomy with surgical drills or saws, a depth parameter is the diploe bleeding when this is achieved and therefore close to the inner cortex (Strong \& Moulthrop). However, in this technique there can be complications such as injuries to the dura mater, which may bring irreversible complications (Sbordone et al.). Knowing this, the removal of the grafts must be done carefully, by trained professionals to do so.

We agree with Carvalho et al. (2006) that determines the depth of the osteotomy with a manually conducted bur. This is easily handled, highlighting the external cortex, diploe to the limits of the inner table. Moreover, during a trepanation is collected bone particles that we know are rich in Bone morphogenetic proteins, which can be used in the maxillary sinuses and / or to fill spaces between the blocks.

In conclusion, the use of titanium mesh for reanatomization of bone defects created in the grafts is well indicated for bald patients.

FERREIRA, G. R.; FAVERANI, L. P.; JARDIM, E. C.; ROSSI, A. C.; POLO, T. O. B.; FILHO, O. M.; OKAMOTO, R. \& JÚNIOR, I. R. G. Particularidades en la técnica quirúrgica de injerto de calota. IInt. J. Odontostomat., 6(3):317-322, 2012.

RESUMEN: Los injertos de calvaria proporcionan una buena cantidad de hueso para la reconstrucción del maxilar atrófico, y tienen menores tasas de morbilidad y reabsorción en comparación con la cresta ilíaca. El objetivo de este trabajo es presentar la técnica para la obtención de un injerto del cráneo. Inicialmente, la profundidad de la osteotomía se determina mediante una fresa manualmente, lo que establece los límites de las estructuras del cráneo (tabla externa, diploe y tabla interna), lo que hace la eliminación de bloques óseos más fácil y segura. Por lo tanto, las osteotomías de los bloques se hacen con mayor seguridad, evitando las complicaciones inherentes a la técnica quirúrgica. Se presenta el caso de un paciente hombre de 65 años que se negó a ser sometido a injerto de cresta ilíaca, optando por la bóveda craneal, a pesar de ser calvo, que es una contraindicación para esta modalidad de tratamiento. Una sutura cuidadosa asociada con la colocación de malla de titanio para mantener la conformación del cráneo del paciente en la región del defecto óseo creado después de obtención del injerto, deja un buen resultado cosmético en el sitio donante. El uso de malla de titanio para la re-anatomización de defectos óseos creados en los injertos está bien indicada para pacientes calvos.

PALABRAS CLAVE: cráneo, mandíbula, atrofia; osteotomía. 


\section{REFERENCES}

Albrektsoon, T.; Brånemark, P. I.; Hansson, H. A. \& Lindström, J. Osseointegrated titanium implants. Requirements for ensuring a long-lasting, direct boneto-implant anchorage in man. Acta Orthop. Scand., 52(2):155-70, 1981.

Carvalho, P. S. P.; Bassi, A. P. F.; Garcia-Júnior, I. R.; França, M. T. \& Ponzoni, D. Maxillary reconstruction using calvarial bone grafts. Technique and operatories difficulties. Implant News, 3:572-7, 2006.

Faverani, L. P.; Silva Filho, O. G. ; Marzola, C.; Pastori, C. M.; Toledo, F. J. L.; Zorzetto, D. L. G.; Capelari, M. M.; Toledo, G. L. \& Ferreira, G. R. Cirurgias ortognáticas e alterações tegumentares decorrentes frente às análises de ortodontistas e cirurgiões buco maxilo faciais. Rev. Odontol., 4: 227-41, 2010.

Frodel, J. L. Jr.; Marentette, L. J.; Quatela, V. C. \& Weinstein, G. S. Calvarial bone graft harvest: techniques, considerations and morbidity. Arch. Otolaryngol. Head Neck Surg., 119(1):17-23, 1993.

Iturriaga, M. T. \& Ruiz, C. C. Maxillary sinus reconstruction with calvarium bone grafts and endosseous implants. J. Oral Maxillofac. Surg., 62(3):344-7, 2004.

Nyström, E.; Ahlqvist, J.; Gunne, J. \& Kahnberg, K. E. 10year follow-up of onlay bone grafts and implants in severely reabsorbed maxillae. Int. J. Oral Maxillofac. Surg., 33(3):258-62, 2004.

Orsini, G.; Bianchi, A. E.; Vinci, R. \& Piattelli, A.Histologic evaluation of autogenous calvarial bone in maxillary only bone grafts: a report of 2 cases. Int. J. Oral Maxillofac. Surg., 18(4):594-8, 2003.

Prolo, D. J. Autogenic skull bone grafts to reconstruct large or complex skull defects in children or adolescents. Neurosurgery, 20:279, 1987.

Ramalho-Ferreira, G.; Faverani, L. P.; Grossi-Oliveira, G. A.; Fabris, A. L. S.; Pastori, C. M. \& Silva-Filho, O. G. Smile analysis following orthognathic surgery. Braz. J. Oral Sci., 9:54-8, 2010.

Sbordone, L.; Toti, P. \& Fabris, G. B. M. Volume changes of autogenous bone grafts alveolar ridge augmentation of atrophic maxillae and mandibles. Int. J. Oral Maxillofac. Surg., 38(10):1059-65, 2009.

Schwartz-Arad, D. S. \& Levin, L. Multitier technique for bone augmentation using intraoral autogenous bone blocks. Implant Dent., 16:5-12, 2007.
Sjõstrõm, M.; Sennerby, L. \& Nilson, H. Reconstruction of the atrophic edentulous maxilla with free iliac crest grafts and implants: A3-year report of a prospective clinical study. Clin. Implant Dent. Relat. Res., 9(1):46-59, 2007.

Strong, E. B. \& Moulthrop, T. Calvarial bone graft harvest: A new technique. Otolaryngol. Head Neck Surg., 123(5):54752, 2000.

Correspondence to:

Ellen Cristina Gaetti Jardim

America do Norte St, 373

Jardim Jussara

Araçatuba, Sao Paulo

Zip Code: 16021-295

BRAZIL

Phone number: 5518 9144-3348

Email: ellengaetti@gmail.com

Received: 14-05-2012

Accepted: 12-08-2012 